2）コルトフ：“容量分析の理論”，第 6 版， p. 110 (1955), (共立出版).

3）長野晃三：“金属キレート”, [I], p. 213(1965), (南江堂).

4) 田村交造：本誌，16，193 (1967).

5) 鹿島 哲: 衛生試, 74, 9 (1956).

is

Quantitative determination of weak acids, weak bases and their salts by the absorbance ratio method. (Difference quantitative determination. II.) Bunzō TAmura, Ikuyo Furuyama and Kazuyuki Moriura (Osaka Plant, Takeda Chemical Industries, Ltd., Higashiyodogawa-ku, Osaka-shi)

The absorbance ratio method4) was applied to the quantitative determination of 35 kinds of substances (poly-basic inorganic acids and their salts, alkali salts of organic acids, weak bases and their hydrochlorides, sulfamines and amino acids), which were difficult to be determined precisely by ordinary direct titrations. The determinations were carried out easily, rapidly and accurately, and the standard deviations for all substances tested were within $0.1 \%$.
The determination procedure is as follows:

A sample solution is prepared according to Table I, absorbances at $\lambda_{1}$ and $\lambda_{2}$ are measured, and the $r$ value is calculated from formula (1). Then the $x$ value is estimated from the $r$ value and the working curve which is obtained from Table II, and the content $z$ is calculated from formula (5), where,

$S:$ the weight of the sample taken $(\mathrm{mg})$.

$C:$ the equivalent of the sample $(\mathrm{mg} / \mathrm{ml})$.

$f$ : the normality factor of the standard solution.

$V^{\prime}$ : the volume of the standard solution added $(\mathrm{ml})$.

The standard solution is usually added with a whole pipet, and then the range of $S$ is given by formula (3) and Table II, where,

$x_{1}$ and $x_{2}$ : the lower and the upper limits of the suitable range of $x$.

$z_{1}$ and $z_{2}$ : the lower and the upper limits of the probable content.

If the weight of sample is not within the range of $S$, the pipet or the buret shown in Fig. 1 is successfully used in place of a whole pipet.

(Received Aug. 11, 1967)

\title{
原子吸光分析による亜鉛の定量ならびに 人血清互鉛定量への応用*
}

\author{
松本 裕之, 常 松 潔, 白石 忠雄**
}

\begin{abstract}
原子吸光分析による亜鉛定量の際の測定条件，各種酸の亜鉛吸光度に及ほす影響，人血清亜鉛定量へ の応用につき検討した。酸のうちで硝酸および過塩素酸はほとんど影響はなかった。トリクロル酢酸お よび硫酸においては低濃度の場合は影響なかったが，高濃度になるとかなりの影響がみられた。人血清 亚鉛定量の際，前処理として 5 倍単純希釈を行なった。本分析法は従来採用していた dithizone 法に比 ベて，迅速性・簡易性の点ではるかにすぐれており，測定誤差も $2.5 \%$ 以内と良好であった。以上の方 法による人血清亜鉛定量の実際例についても示した。
\end{abstract}

\section{1 緒訔}

著者注数年来, 渚種疾患, 特に肝, 覀性しゅよう疾患 衫ける亜鉛代謝の異常につき検索してきたが，西鉛定 量法としては dithizone 法112)を採用していた。この方 法法試薬の調製, 器査の洗浄, 検体の処理, 測定操作去 ごすべての段階で複雑な手技老必要とし，そのために長

* 原子吸光分析による生体試料の亜鉛の定量(第 1 報)

** 北海道大学医学部第三内科学教室：札幌市北 14 条 西 5 丁目
時間を費やし，検体損失および活染の危険性も大きい， しかし原子吸光分析法の出現によって，これらの難点が 一挙に解決されることとなった。

原子吸光分析法法，1955 年オーストラリアわ Walsh3) によって実用化されて以来急速な発展を遂げ，医学，農 学，工学，共のほか多くの方面に応用されつつ方る。亜 鉛惊子吸光分析法化おいて最も感度の高い元素の一つ で西り，多くの応用例がみられる4) 15)，著者らは今回 本分析による亜鉛定量の際の測定条件，各種酸の亜鉛吸 光度に及汪す影響，人血清亜鉛定量への応用につき検討 
定加えたのだ，その結果を報告する。

\section{2 装置および試薬}

\section{$2 \cdot 1$ 装}

装置は日立 207 型原子吸光分光光度計を使用した。本 装置に打けるメーターの読み（scale reading）汲光度 を比例拡大したものとして表わしてある。

\section{2 試 薬}

亜鉛標準液：金属亜鉛 $(99.99 \%) 1.00 \mathrm{~g}$ を少量の塩 酸に溶解したのち, 脱イオン水(蒸留水を一度 Amberlite IR 120, Amberlite IRA 410 のカラムを通したあ と, 再度 Amberlite IR 120 のカラムを通したもの) で 希䣋乙て亜鉛標準液 ( $\mathrm{Zn}: 1000 \mathrm{ppm})$ を調製し，使用 時にこれを希釈して用いた。

その他の試薬はすべて特級品を使用した。

\section{3 測定条件}

測定は Table I の条件のもとで行なったが，これら の值感度および精度を最高に保つように実験的に求め たものである。

Table I Condition of measurement

\begin{tabular}{ll}
\hline Wavelength & $2139 \AA$ \\
Source & $8 \mathrm{~mA}$, hollow cathode lamp \\
Burner & Stainless steel, premix \\
& Vertical position $(1)$ \\
Air & Pressure $: 1.8 \mathrm{~kg} / \mathrm{cm}^{2}$ \\
& Flow rate $: 13.0 \mathrm{l} / \mathrm{min}$ \\
Fuel & Acetylene, pressure $: 0.5 \mathrm{~kg} / \mathrm{cm}^{2}$ \\
& Flow rate $: 2.5 l / \mathrm{min}$ \\
\hline
\end{tabular}

\section{1 バーナーの高さについて}

装置にはバーナーの高さを示すめやすとして，(0)〜 (3)のマークがついており, マーク(0)の位置は光束とバ ーナーの先端の間隔が $20 \mathrm{~mm}$ で，以下 $5 \mathrm{~mm}$ ごとに マークが示されている.アセチレンガス流量と空気流量 の割合を一定にして，これらを变化させたときの各バー ナ一位置における吸光度の变化を Fig. 1 に示す.

Fig. 1 からわかるように, 各バーナ一位置における吸 光度に著明な差異はみられなかったが，マーク (1) の 位置においてわずかに感度が高くなる傾向にあった。乙 たがってバーナー位置をマーク（1）に選定した。

\section{2 アセチレン流量について}

空気流量を $13.0 \mathrm{l} / \mathrm{min}$ と一定に保ち, アセチレン流 量を変化させたときの吸光度の変化を Fig. 2 に示す.

Fig. 2 からわかるように，アセヂレン流量が少なくな るほど感度は高くなるが，アセチレン流量が $2.0 \mathrm{l} / \mathrm{min}$

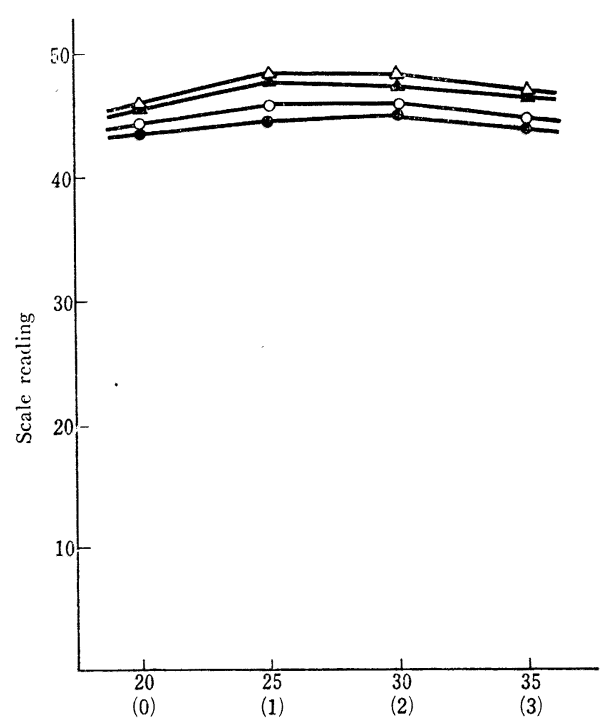

Length of flame above burner top, $\mathrm{mm}$

Fig. 1 Effect of variation of acetylene air mixture and burner height on the sensitivity for zinc

( ) Burner height position(in marks); The acetylene flow rate of acetylene and air were varied as shown. Sample : 1.0ppm Zn standard solution; Wavelength :

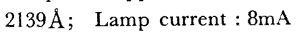

$\begin{array}{lll} & \text { Acetylene } & \text { Air } \\ -\triangle- & 2.0 l / \mathrm{min}, & 12.0 \mathrm{l} / \mathrm{min} \\ -\mathbf{\Delta} & 2.5 \mathrm{\prime \prime}, & 13.0 \mathrm{\prime \prime} \\ -\bigcirc- & 3.0 \mathrm{\prime}, & 13.0 \mathrm{\prime \prime} \\ -\mathbf{-} & 3.5 \mathrm{\prime}, & 14.0 \mathrm{l}\end{array}$

の場合は炎の状態が不安定となるので, アセチレン流量 としては $2.5 \mathrm{l} / \mathrm{min}$ を選定した。

\section{3 ランプ電流について}

中空陰極ランプの作動電流值を变化させたときの吸光 度の変化を Fig. 3 に示す. 一般にランプ作動電流值が 小さくなるほど感度は高くなるといわれ(12)16)17), Fig. 3 も同様な傾向它示している. またランプ寿命の点からも ランプ電流值はなるべく小さいことが望ましいが，あま り電流值が小さすぎるとノイズが大きくなり誤差の原因 となる・そこで著者らは $8 \mathrm{~mA}$ を測定電流值とした。

\section{4 検量線および酸の影響}

\section{$4 \cdot 1$ 検量線}

$2 \cdot 2$ の亜鉛標準液を 希釈して種々濃度の溶液を 調製 し，Table I の条件に従って測定した結果を Fig. 4, 5 に 示す. Fig. 4 はスケール拡大せずに比較的高濃度 (0.5, $1.0,1.5,2.0 \mathrm{ppm})$ につき, Fig. 5 はスケール拡大 3 


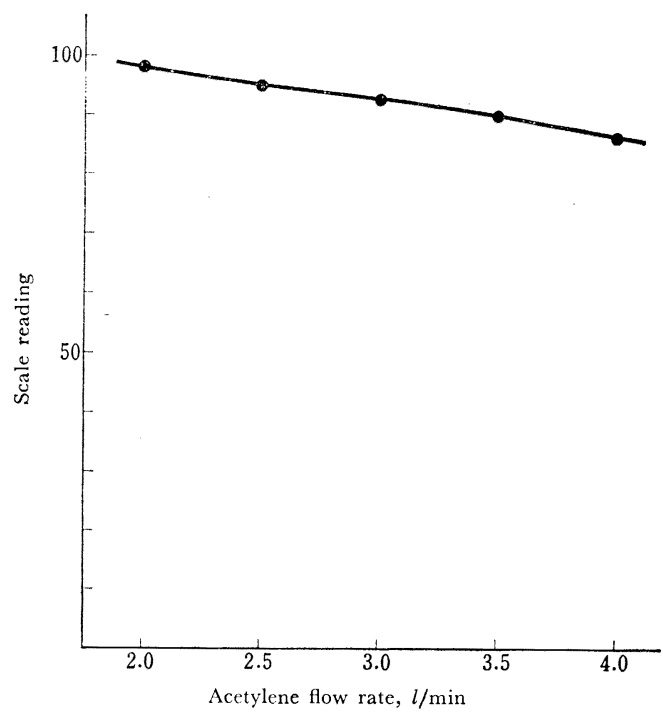

Fig. 2 Effect of variation of acetylene flow rate on the sensitivity for zinc

The flow rate of air was constant at $13.0 \mathrm{l} / \mathrm{min}$, and that of acetylene was varied. Sample : $3.0 \mathrm{ppm} \mathrm{Zn}$ standard solution; Wavelength : 2139 $\AA$; Lamp current : $8 \mathrm{~mA}$, Burner height : Position (1)

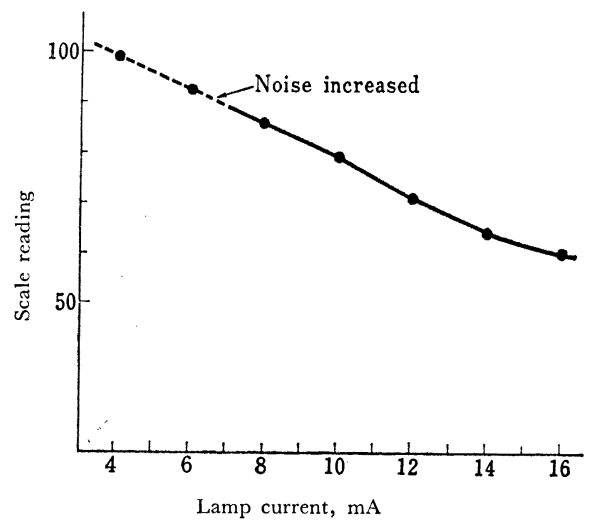

Fig. 3 Effect of lamp current on the sensitivity for zinc

Sample : $2.0 \mathrm{ppm} \mathrm{Zn}$ standard solution; Wavelength : $2139 \AA$; Air flow rate: $13.0 \mathrm{l} / \mathrm{min}$; Acetylene flow rate $: 25 \mathrm{l} / \mathrm{min}$; Burner height : Position(1)

倍で比較的低浱度 $(0.1,0.2,0.3,0.4 \mathrm{ppm})$ につき 作成した検量線である・いずれの場合も良好な值線関係 宗している。

\section{2 酸の影響}

種々の酸の业鉛吸光度に及ぼす影響を検討した結果を

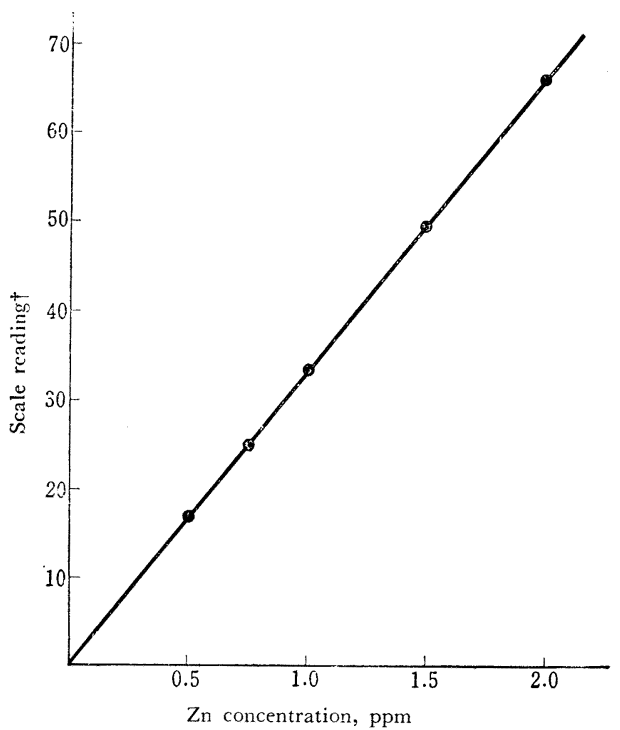

Fig. 4 Calibration curve for zinc

$$
\dagger \text { No scale expansion }
$$

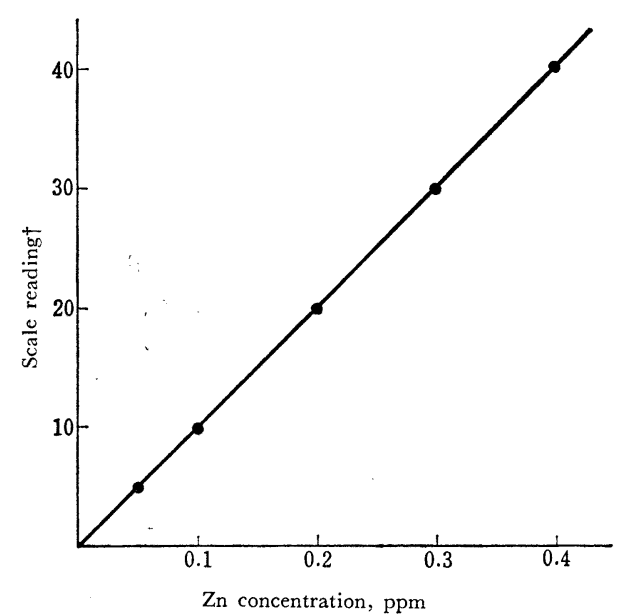

Fig. 5 Calibration curve for zinc

$$
\dagger \text { Three fold scale expansion }
$$

Table II に示す. この場合 ブランクとして溶媒である 各種酸溶液を用いた。 Table II に示した吸光度はそれ ぞれの溶媒の吸光度で補正したものである. 硫酸の場合 高濃度 $(10 \%, 25 \%)$ では明らかに吸光度が減少する が，低濃度（1\%，5\%) ではほとえど影響はみられず， 硝酸, 過塩素酸の場合はいずれの濃度においても著明な 影響はみられなかった。これらについては文献とも一致 する4)5)。しかしトリクロル酶酸の場合低濃度では影響 
Table II Effect of various acids on the atomic absorption of zinc

\begin{tabular}{|c|c|c|c|c|}
\hline \multirow{2}{*}{ Acids } & \multirow{2}{*}{$\begin{array}{l}\text { Concn. } \\
(\%) \\
(v / v)\end{array}$} & \multicolumn{3}{|c|}{ Absorption $\dagger$} \\
\hline & & $\begin{array}{l}0.25 \mathrm{ppm} \\
\text { of zinc }\end{array}$ & $\begin{array}{l}0.5 \mathrm{ppm} \\
\text { of zinc }\end{array}$ & $\begin{array}{l}1.0 \mathrm{ppm} \\
\text { of zinc }\end{array}$ \\
\hline Sulfuric acid & $\begin{array}{r}0 \\
1 \\
5 \\
10 \\
25\end{array}$ & $\begin{array}{r}12.6 \\
12.7 \\
11.9 \\
9.6 \\
4.8\end{array}$ & $\begin{array}{l}25.4 \\
26.2 \\
24.8 \\
20.4 \\
10.5\end{array}$ & $\begin{array}{l}51.3 \\
51.9 \\
51.2 \\
38.3 \\
26.3\end{array}$ \\
\hline Nitric acid & $\begin{array}{r}0 \\
1 \\
5 \\
10 \\
25\end{array}$ & $\begin{array}{l}12.3 \\
12.3 \\
12.2 \\
12.2 \\
12.4\end{array}$ & $\begin{array}{l}24.8 \\
24.9 \\
24.9 \\
24.9 \\
23.9\end{array}$ & $\begin{array}{l}51.4 \\
51.5 \\
50.2 \\
49.5 \\
49.0\end{array}$ \\
\hline Perchloric acid & $\begin{array}{r}0 \\
1 \\
5 \\
10 \\
25\end{array}$ & $\begin{array}{l}12.8 \\
13.1 \\
13.0 \\
12.4 \\
12.5\end{array}$ & $\begin{array}{l}25.5 \\
26.0 \\
25.5 \\
25.0 \\
24.5\end{array}$ & $\begin{array}{l}50.4 \\
51.0 \\
50.5 \\
50.0 \\
48.5\end{array}$ \\
\hline $\begin{array}{l}\text { Trichloroacetic } \\
\text { acid }\end{array}$ & $\begin{array}{r}0 \\
1 \\
5 \\
10 \\
25\end{array}$ & $\begin{array}{l}12.5 \\
12.0 \\
12.0 \\
15.0 \\
16.5\end{array}$ & $\begin{array}{l}24.5 \\
26.0 \\
25.5 \\
30.5 \\
31.5\end{array}$ & $\begin{array}{l}50.0 \\
51.0 \\
52.0 \\
60.0 \\
65.0\end{array}$ \\
\hline
\end{tabular}

$\dagger$ Each value is a scale reading.

はなかったが，高濃度になるとかえって吸光度が増加与 る傾向を示した、トリクロル酰酸についてはほとえど影 響がなかったという報告もみられるが11，トリクロル酢 酸の影響についての詳細な報告はなされていない.

\section{5 人血清亜鉛定量}

\section{$5 \cdot 1$ 前処理について}

血清亜鉛量を原子吸光分析により定量する場合，前処 理法としては脱イオン水による単純希橎法およびトリク ロル酶酸による除たん白法（以下 T. G. A. 法と略記） そのほかがある．著者らは健康人血清についてこの 2 種 類の前処理法を比較検討した。すなわち種々の倍数に単 純希釈した血清の系列と, 最終濃度が $5 \%$ となるように トリクロル酰酸を加えて同じ倍数に希釈した除たん白血 清の系列を作り，それぞれ対応する倍数の希䣋血清の吸 光度を測定比較した．この際 $5 \%$ トリクロル酢酸は 4.2 にみるように吸光度に影響を及ぼさない。結果を Table
III に示す. Table III からわかるように，2４ 倍希釈 においては単純希䣋法のほうが T. C. A. 法よりも高い 吸光度を示し，6倍希釈以上になると両法ともほぼ同じ 吸光度を示した。

さらに単純希勫法の場合に希䣋倍数と吸光度の相関関 係を検討した結果を Fig. 6 に示与. Fig. 6 からわかる ように，4〜5 倍希釈以上の場合に注ぼ直線関係が得ら れた。このように希釈倍数が小さい場合すなわ台血清と しての濃度が高い場合に, 吸光度が直線関係からずれて くるのは, たえ白濃度, 粘度などの影響によりアトマイ ザーを通過する検体の量が減少してくるためと思われ る.

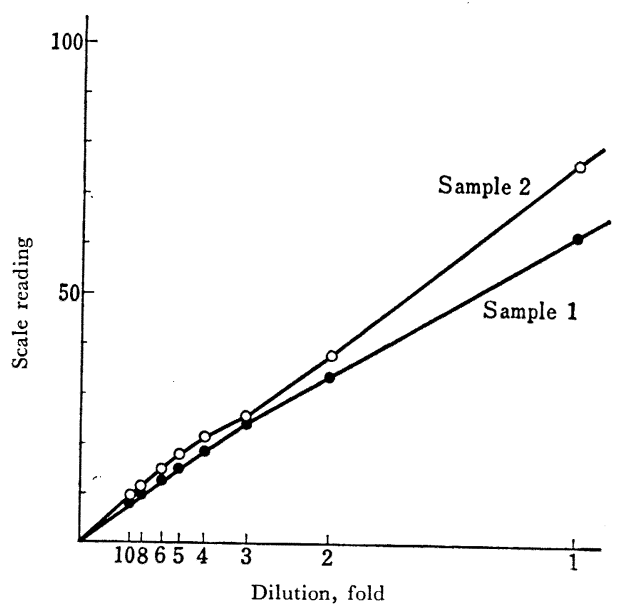

Fig. 6 Relation of absorption and dilution in the determination of zinc in human serum

以上の結果から，血清の前処理法として 5 倍単純希勫 を採用した。

\section{$5 \cdot 2$ 回収実験}

健康人血清に前記亜鉛標準溶液它加えて，亜鉛の添加

Table III Comparison of simple dilution method with T. C. A. method in the determination of zinc in human serum

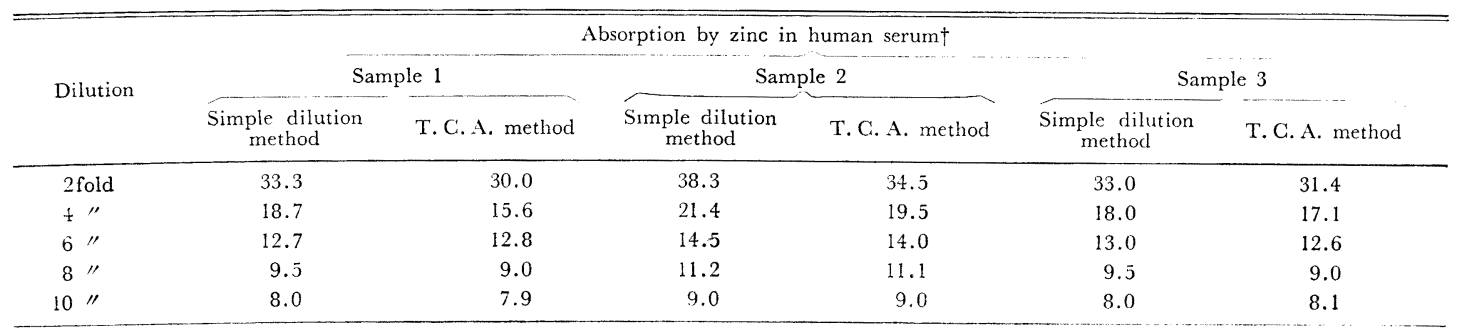

Represented by scale readings 
Table IV Recovery of ( $0.5 \mathrm{ppm}$ of) zinc added to serum

\begin{tabular}{|c|c|c|c|c|c|c|}
\hline \multirow{2}{*}{ Dilution } & \multicolumn{2}{|c|}{ Sample 1} & \multicolumn{2}{|c|}{ Sample 2} & \multicolumn{2}{|c|}{ Sample 3} \\
\hline & Found (ppm) & Recovery $(\%)$ & Found (ppm) & Recovery (\%) & Found (ppm) & Recovery $(\%)$ \\
\hline 2 fold & 0.380 & 76.0 & 0.378 & 75.6 & 0.378 & 75.6 \\
\hline $4 \prime \prime$ & 0.480 & 96.0 & 0.467 & 93.4 & 0.464 & 92.8 \\
\hline $5 \prime \prime$ & 0.480 & 96.0 & 0.481 & 96.2 & 0.472 & 94.4 \\
\hline $6 " 1$ & 0.450 & 90.0 & 0.490 & 98.0 & 0.480 & 96.0 \\
\hline $8 \prime \prime$ & 0.466 & 93.2 & 0.486 & 97.2 & 0.474 & 94.8 \\
\hline $10 " \prime$ & 0.476 & 95.2 & 0.490 & 98.0 & 0.478 & 95.6 \\
\hline
\end{tabular}

量が $0.5 \mathrm{ppm}$ となるように種々の倍数に希釈して各希 釈血清に抢ける回収率を調べた。 Table IV に示すよう に，2 倍希勫の場合では回収率はわるかった４倍希譒 以上になるといずれの場合も $95 \%$ 前後の回収率を示し たが，希釈倍数と回収率との間に特に相関関係はみられ なふった２倍希釈の場合に特に回収率がわるいのはや はり5・1で述べたような理由によるものであろう。

\section{3 再現性について}

健康人血清 3 檢体について前処理として 5 倍に単純希 釈したの方，連䋨 5〜10 回の测定を行ない測定值のばら つき文調べた. Table V に示すように相対誤差はいず 机の場合も $2.5 \%$ 以内であった。

Table V Reproducibility of the determination of zinc in serum

\begin{tabular}{cccc}
\hline \hline \multirow{2}{*}{ No. of analysis } & \multicolumn{3}{c}{ Serum zinc level $(\mu \mathrm{g} / \mathrm{d} l)$} \\
\hline 1 & Sample 1 & Sample 2 & Sample 3 \\
\hline 2 & 105 & 78 & 93 \\
3 & 102 & 80 & 90 \\
4 & 105 & 78 & 93 \\
5 & 105 & 74 & 93 \\
6 & 102 & 76 & 90 \\
7 & 108 & 75 & \\
8 & 105 & 76 & \\
9 & 105 & 75 & \\
10 & 106 & 76 & \\
Mean \pm Stand. dev. & $104.2 \pm 2.04$ & $76.6 \pm 1.75$ & $91.8 \pm 1.46$ \\
Coefficient of & 2.0 & 2.3 & 1.6 \\
variation $(\%)$ & 102 & 78 & \\
\hline
\end{tabular}

\section{4 血清悪鉛定量例}

原子吸光分析により種々の状態の人血清について亜鉛

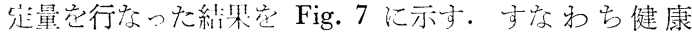
人血清 15 例，留性しゅよう孚よび肝疾患患者血清各 5

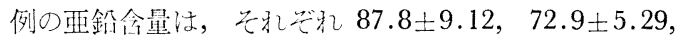
$59.7 \pm 3.39 \mu \mathrm{g} / \mathrm{d} l$ であった。この結果から悪性しゅよ

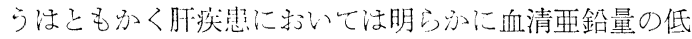
下゙多ら机た。し㐓しいず机にしても例数が少ないの

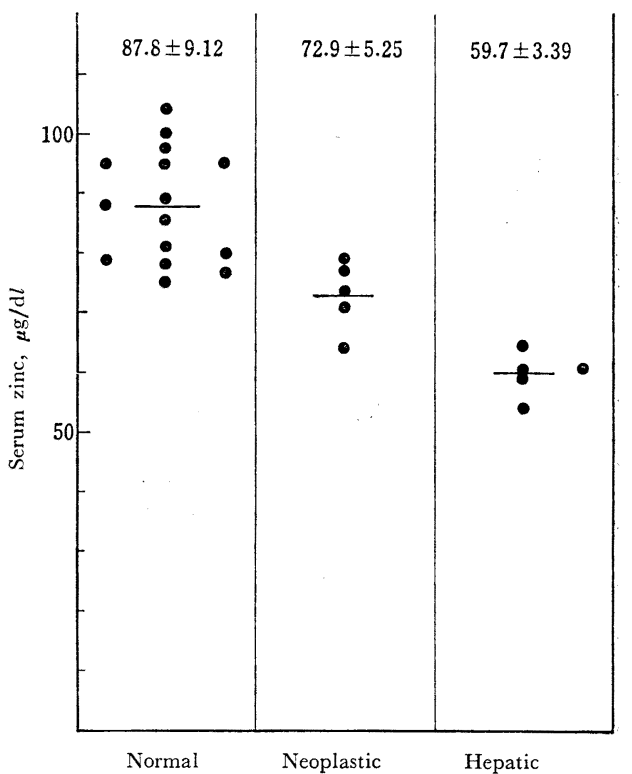

Fig. 7 Serum zinc level by various diseases

で，今後例数を重水なお検討を加える必要がある。

$$
6 \text { 結言 }
$$

（1）原子吸光分析による亜鉛定量の際の測定条件 実験的に求めた。

（2）高濃度の硫酸は亜鉛吸光度を減少させ，高濃度 のトリクロル酢酸は吸光度を増加させるが，低濃度の硫 酸およびトリクロル䣷酸において沙影響は夕られなかっ た。また硝酸および過塩素酸はいずれの濃度においても 影響がなかった。

（3）血清亜鉛定量の際前処理としては単純希釈が簡 単でよい.

（4） dithizone 法による血清亚鉛定量に要する時間 は 1 検体の場合 4 時間前後であるが，本分析法走用いる と 30 分しか要せず分析の迅速化，簡易化学注引ること ができる、したがって検体の損失，汗染の危険もきわ㳗 て少ない。また再現性に出いて性誤差 $2.5 \%$ 以内之かな 
り良好な精確度を示した。

（5）添加回収実験において注，4 倍希橎以上の血清 の場合に回収率 $95 \%$ 前後々いう成績安得た.

（6）原子吸光分析による人血清严鉛定量の実際例住 ついて示した.

\section{交献}

1) B. G. Malmström: "Methods of Biochemical Analysis", 2nd Ed., Vol. 3, p. 340 (1956), (Interscience Publishers Inc., New York).

2) H. P. Wolff: Biochem. Z., 325, 267 (1954).

3) A. Walsh: Spectrochim. Acta, 7, 108 (1955).

4) D. J. David: Analyst, 83, 655 (1958).

5) J. A. F. Gidley, J. T. Jones: ibid., 85, 249 (1960).

6) J. A. F. Gidley, J. T. Jones : ibid., 86, 271 (1961).

7) J. E. Allan: ibid., 86, 530 (1961).

8) J. B. Willis: Anal. Chem., 34, 614 (1962).

9) L. Erdey, G. Svehla, L. Koltai: Talanta, 10, 531 (1963).

10) K. Fuwa, P. Pulido, R. Mckay, B. L. Vallee: Anal. Chem., 36, 2407 (1964).

11) A. S. Prasad, D. Oberleas, J. A. Halsted: J. Lab. \& Clin. Med., 66, 508 (1965).

12) T. L. Change, T. A. Gover, W. W. Harrison: Anal. Chim. Acta, 34, 17 (1966).

13) H. L. Helwig, E. M. Hoffer, W. C. Thielen, A. E. Alcocer, D. R. Hotelling, W. H. Rogers, J. Lench: Am. J. Clin. Path., 45, 156 (1966).
14) B. Hackley, J. G. Smith: Fed. Proceed., 26, 524 (1967).

15) M. M. Parker, F. L. Humoller, D. J. Mahler: Clin. Chem., 13, 40 (1967).

16) B. J. Russel, A. Walsh, J. P. Shelton: Spectrochim. Acta, 8, 317 (1967).

17) J. E. Allan: Analyst, 83, 466 (1958).

$$
\text { is }
$$

Determination of zinc by atomic absorption spectroscopy and its application to the analysis of human serum. (Determination of zinc in biological materials by atomic absorption spectroscopy. I.) Hiroshi Matsumoto, Kiyoshi Tsunematsu and Tadao Shiraishi (The Third Department of Internal Medicine, School of Medicine, Hokkaido University, Sapporo-shi)

Measurement parameters in the atomic absorption method for the determination of zinc together with the influences of various acids were investigated, with an aim of its application to the analysis of human serum.

Nitric acid and perchloric acid had no influences. Trichloroacetic acid and sulfuric acid influenced remarkably in higher concentrations. A simple 5 fold dilution of the sample as the preliminary treatment was sufficient for the analysis of human serum.

The proposed method was far more rapid and simple than the conventional dithizone method, and the relative error was within $2.5 \%$. Several examples of determination of zinc in serum were given.

(Received Aug. 31, 1967)

\title{
混合製剤中のアセチルサリチル酸アルミニウムの定量*
}

\author{
立沢 政義**，下田 通敏***
}

\begin{abstract}
赤外線吸収スペクトル法による混合製剂中のアセチルサリチル酸アルミニウムの定量法を確立した.
フセチルサリチル酸丁ルミニウムはトリエタノールフミンおよびフッ化水素フンモニウムと反応させ ると，分解して可溶性のトリエタノールアミンーフセチルサリシレートとなる。これは $1750 \mathrm{~cm}^{-1}$ を key band とすればー成分系として混合製片中のアセチルサリチル酸アルミニウムの定量ができる.
\end{abstract}

\section{1 緒言}

総合感冒剂の処方規準改正により最近非ピリン系解熱

* 赤外線吸収スペクトルによる医薬品の分析的研究 (第 2 報). 第 1 報は立沢政義 : 衛生試, 83, 53(1965)

** 国立衛生試験所医薬品部: 東京都世田谷区玉川用賀 町 2 丁目

*** 昭和薬品化工株式会社開発研究部 : 神奈川県川崎市 下野毛字久保東
鎮痛凨としてアセチルサリチル酸アルミニウム（以下 ASAl と略記）を配合した処方が多くなった。

現在 ASAl の定量法として塩酸酸性でフッ化ナトリウ ムを加光て分解し, クロロホルム抽出後紫外部吸収法122)

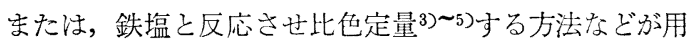
いられている.

これらの方法は操作が繁雑で, 吢つ共存するサリチル 酸の影響があるため総サリチル酸量より，共存サリチル 